This article was downloaded by: [suryadi ismadji]

On: 03 April 2012, At: 15:03

Publisher: Taylor \& Francis

Informa Ltd Registered in England and Wales Registered Number: 1072954 Registered office: Mortimer House, 37-41 Mortimer Street, London W1T 3J H, UK

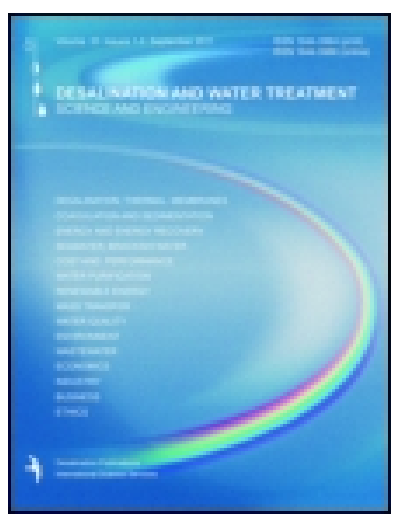

\title{
Desalination and Water Treatment
}

Publication details, including instructions for authors and subscription information: http:// www. tandfonline.com/loi/tdwt20

\section{Adsorption of $\mathbf{N}$-methylated diaminotriphenilmethane dye (malachite green) on natural rarasaponin modified kaolin}

\author{
Anita Carolina Suwandi, Nani Indraswati \& Suryadi Ismadji ${ }^{a}$ \\ ${ }^{a}$ Department of Chemical Engineering, Widya Mandala Surabaya Catholic University, \\ Kalijudan 37, Surabaya, 60114, Indonesia Phone: Tel. +62 313891264 Fax: Tel. +62 31 \\ 3891264
}

Available online: 29 Mar 2012

To cite this article: Anita Carolina Suwandi, Nani Indraswati \& Suryadi Ismadji (2012): Adsorption of N-methylated diaminotriphenilmethane dye (malachite green) on natural rarasaponin modified kaolin, Desalination and Water Treatment, $41: 1-3,342-355$

To link to this article: http:// dx. doi.org/ 10.1080/ 19443994.2012.664738

\section{PLEASE SCROLL DOWN FOR ARTICLE}

Full terms and conditions of use: http://www.tandfonline.com/page/terms-and-conditions

This article may be used for research, teaching, and private study purposes. Any substantial or systematic reproduction, redistribution, reselling, loan, sub-licensing, systematic supply, or distribution in any form to anyone is expressly forbidden.

The publisher does not give any warranty express or implied or make any representation that the contents will be complete or accurate or up to date. The accuracy of any instructions, formulae, and drug doses should be independently verified with primary sources. The publisher shall not be liable for any loss, actions, claims, proceedings, demand, or costs or damages whatsoever or howsoever caused arising directly or indirectly in connection with or arising out of the use of this material. 


\title{
Adsorption of N-methylated diaminotriphenilmethane dye (malachite green) on natural rarasaponin modified kaolin
}

\author{
Anita Carolina Suwandi, Nani Indraswati, Suryadi Ismadji* \\ Department of Chemical Engineering, Widya Mandala Surabaya Catholic University, Kalijudan 37, Surabaya \\ 60114, Indonesia \\ Tel. +62 31 3891264; Fax: +62 31 3891267; email: suryadi@mail.wima.ac.id
}

Received 24 November 2011; Accepted 22 January 2012

\begin{abstract}
A B S T RACT
The modification of kaolin using natural surfactant rarasaponin was studied. The effectiveness of kaolin and rarasaponin-kaolin was evaluated for removal of malachite green (MG) from the aqueous solution. The temperature dependent forms of Langmuir, Freundlich, Sips and Toth model were employed to correlate the adsorption experimental data. Even all isotherms used in this study, visually can correlate the experimental data well, however Sips model gave consistent and reasonable values of the fitted parameters. Kinetic data were analyzed using pseudo-first- and pseudo-second-order, and pseudo-first-order gave reasonable values of fitted parameters. Thermodynamic properties of adsorption of MG onto kaolin and rarasaponin-kaolin were also obtained in this study.
\end{abstract}

Keywords: Adsorption; Modification; Kaolin; Rarasaponin-kaolin

\section{Introduction}

Synthetic dyes have been widely used in many industrial processes. Some kinds of these dyes are safe and can be used for food colouring others are very toxic for human and even for the environment. Currently, synthetic dyes in industrial processes almost replace natural dyes due to its cheaper price, brighter colour and better properties to the dyed materials. Many of these dyes are dangerous and must be removed before getting discharged to environment. Even at very low concentration, the presence of dye in water could be highly toxic to aquatic systems [1]. Also, the presence of dye in water may influence aquatic ecosystem which is due to acute and/or chronic effects on the exposed organisms, depending on the exposure time and dye concentration, or by

*Corresponding author. blocking the passage of light through the water so it can interfere with the growth of microorganisms and hinder photosynthesis in aquatic plants [2-4]. Several dyes cannot be removed completely by conventional biological treatment processes, such as activated sludge and anaerobic digestion, since they are also resistant to light and moderate oxidative agents [5].

Basic Green 4 (BG 4) or malachite green (MG) is a cationic dye that belongs to $\mathrm{N}$-methylated diaminotriphenylmethane dye and most widely used for colouring purpose among all other dyes of its category [3]. This dye is used as biocide in the aquaculture industries. It is also used as colouring agent in leather, wool, jute, paper, cotton, silk and acrylic industries as well as food coloring agent, food additive, medical disinfectant and anthelminthic [3,6,7]. However, MG is hazardous, carcinogenic and acts as a liver promoter [8]. It causes damage to liver, kidney, spleen and heart; decreases growth, food intake and 
fertility rates; inflicts lesions on eyes, skin, lungs and bones [9]. MG easily reduces the tissue of fish and mice to persistable leuco-MG, which acts as a tumor promoter $[10,11]$. Several studies also reveal that the degradation products of MG have carcinogenic potential $[9,12]$. However, despite a lot of data on its toxic effects, MG is still used in aquaculture and many other industries [3,13-16]. Therefore, the removal of BG 4 from effluents is very essential to protect the water resources [9].

Several commonly used methods for the removal dyes from wastewater are adsorption, nanofiltration, electrocoagulation, coagulation and precipitation, chemical oxidation, electrochemical oxidation, photooxidation, colloidal gas aphrons, ozonation, supported liquid membrane and liquid-liquid extraction [15,17]. The advantages and disadvantages of each method have been reviewed in several papers [17-24]. Among these mentioned methods, adsorption process are more attractive due to their high efficiency, low-cost, very simple design, availability and easy for recovery and reuse of adsorbent [5,19]. Moreover, adsorption can remove toxic chemicals without lowering the quality of water or leaving any hazardous degraded products in comparison to biochemical, electrochemical or photochemical degradation processes [25].

Granular activated carbon (GAC) is the most widely used adsorbent [26]. Activated carbon adsorption shows high effectiveness in removal of organic and inorganic pollutants, including dyes and pigments. However, the use of this adsorbent in wastewater treatment is still limited because of its high cost and difficulty in regeneration. This fact triggers research and development for another low-cost adsorbents, such as clay [16,27-30], bagasse [31], chestnut shell [32], banana peel [33,34], chitosan [35,36] and many more.

Clay has been used for different kinds of application [37,38], and one of the application is in adsorption area. One of the most commonly used clay as low-cost adsorbent is kaolin with $\mathrm{Al}_{2} \mathrm{Si}_{2} \mathrm{O}_{5}(\mathrm{OH})_{4}$ or $\mathrm{Al}_{2} \mathrm{O}_{3} \cdot 2 \mathrm{SiO}_{2} \cdot 2 \mathrm{H}_{2} \mathrm{O}$ chemical structure that belongs to the natural alumino silicate clay adsorbents. Kaolinite clay has been studied as an adsorbent for removal of heavy metal ions and organic contaminants from aqueous medium [39]. The chemical composition of kaolinite, $\mathrm{SiO}_{2}: 40 \mathrm{~mol} \%, \mathrm{Al}_{2} \mathrm{O}_{3}: 20 \mathrm{~mol} \%$ and $\mathrm{H}_{2} \mathrm{O}: 40 \mathrm{~mol} \%$. Kaolin crystal structure is composed of a two-layer triclinic structure, consisting of stacked pairs of tetrahedral silica sheets and octahedral alumina sheets. The oxygen atoms hold each pair of sheets together, while successive pairs are bound by hydrogen bonding between silica-oxygen and aluminumhydroxyl groups. The surfaces of kaolinite are predicted to have a constant structural negative charge, due to the isomorphous substitution of $\mathrm{Si}^{4+}$ by $\mathrm{Al}^{3+}$ in the silica layer, while the charge on the alumina face and on the edges is caused by the protonation/deprotonation of exposed hydroxyl groups which depends on the $\mathrm{pH}$ value of the solution $[40,41]$. There are large quantities of kaolin in Indonesia because it is one of abundant natural resources, therefore it may be used as an alternative adsorbent due to its stability in water, low cost and potential adsorption application.

Unfortunately, kaolinite has a low-cation exchange capacity (CEC), and therefore it is not expected to be an ion exchanger of high order $[39,42]$. Cationic surfactants have been studied to increase the adsorption capacity of clay for hydrophobic organic contaminants (HOCs) [43]. Therefore, modification using cationic surfactant is necessary to improve kaolin adsorption capacity. The modified kaolin is called organo-kaolin, related to addition of organic compound into the kaolin.

Commonly used surfactants act as modifying agent that are synthetic surfactants, such as cetyltrimethylammonium bromide (CTMAB) [44], octadecyltrimethylammonium bromide (ODTMA) [30], N-[3[(trimethoxysilyl)propyl]diethylenetriamine (MPDET) [45]. These surfactants may have non-biodegradable properties due to its synthetic origin, which may cause environmental problems. For minimizing the problem, ecological friendly natural surfactant was used as modifying agent in this study.

Lerak (Sapindus rarak DC) is easily found in Indonesia, especially in Java. S. rarak DC contains natural surfactant called as rarasaponin, which belongs to sugar derivatives compound that may be found in plants, which is characterized by forming foam when dissolved in water. Rarasaponin has complex chemical structure; different chemical structures of rarasaponin can be found elsewhere [46]. The most widely used method to obtain rarasaponin is solid-liquid extraction (leaching). Different kind of solvents can be used to extract rarasaponin from its solid matrices such as water $\left(\mathrm{H}_{2} \mathrm{O}\right)$, methanol $(\mathrm{MeOH})$, ethanol $(\mathrm{EtOH})$ and sodium methoxyde $(\mathrm{NaOMe})$ [46]. Since rarasaponin is a natural surfactant, therefore it has great potential application as an environmental friendly chemical for modification of kaolin for dye removal.

To the best of our knowledge, currently there is no information about utilization of rarasaponin as surfactant for organo-kaolin preparation; therefore, this is the novelty of our study. In order to test the adsorption capability of rarasaponin-kaolin, the adsorption experiments of MG from aqueous solution were con- 
ducted in batch mode in several temperatures. The adsorption isotherms of MG onto natural kaolin and rarasaponin-kaolin were correlated using temperature dependent forms of Langmuir, Freundlich, Sips and Toth models. The kinetic data were correlated by well known pseudo-first- and pseudo-second-order models.

\section{Materials and methods}

\subsection{Materials}

Kaolin used in this study was obtained from Pacitan, East Java, Indonesia. The kaolin was crushed and sieved using the ASTM standard sieves to obtain 180200 mesh particle size. MG, also known as BG 4, was used as adsorbate. $\mathrm{MG}$ is a cationic $\mathrm{N}$-methylated diaminotriphenylmethane dye, contains $-\mathrm{N}\left(\mathrm{CH}_{3}\right)_{2}$ functional group, C.I. 42000 (certified number for MG), chemical formula $=\mathrm{C}_{23} \mathrm{H}_{25} \mathrm{~N}_{2} \mathrm{Cl}$, FW (formula weight or molecular weight $)=364.7$ and $\lambda_{\max }=$ $616.4 \mathrm{~nm}$. MG was purchased from Sigma Aldrich (analytical grade) and was used without further treatment.

\subsection{Adsorbent characterization}

The CEC of kaolin was determined by the proton exchange method and the value is $67.9 \mathrm{meq} / 100 \mathrm{~g}$. The surface structure crystallography of kaolin was measured on a Rigaku D/Max-2200 X-ray powder diffractometer with $\mathrm{Cu} / \mathrm{K} \alpha(\lambda=0.154 \mathrm{~nm})$ radiation. The diffraction intensities were recorded from 5 to $40^{\circ}$. Identification of functional groups of adsorbents before and after adsorption were conducted using FTIR Spectrophotometer (Shimadzu 8400S). The chemical composition of kaolin and rarasaponin-kaolin was analyzed using Rigaku ZSX100e X-ray Fluorescence.

\subsection{Extraction of rarasaponin}

Rarasaponin used in this study was obtained by extraction of dried fruits of $S$. rarak $D C$ using water as solvent. The fruits were obtained from Klaten, Central Java, Indonesia. Dried fruits of $S$. rarak DC were crushed and sieved in the vibration screen (RETSCH) to obtain 180-200 mesh powder. Twenty grams of $S$. rarak $D C$ powder was mixed with $200 \mathrm{~mL}$ of distilled water and then heated at $353 \mathrm{~K}$ for $60 \mathrm{~min}$. The extract was then centrifuged (Hettich Zentrifugen EBA-20) for $10 \mathrm{~min}$ at $4000 \mathrm{rpm}$ to separate solid from the solution. The supernatant was then concentrated by vacuum evaporation (BUCHI RE 121) and dried in a vacuum drying oven. The rarasaponin crystals were crushed and sieved using vibration screen (RETSCH) to obtain 180-200 mesh powder.

\subsection{Modification of kaolin}

Modification of kaolin was conducted by soaking kaolin in rarasaponin solution for $24 \mathrm{~h}$ at $303 \mathrm{~K}$ under constant stirring at $500 \mathrm{rpm}$. After $24 \mathrm{~h}$, the solution was centrifuged at $4500 \mathrm{rpm}$ for $5 \mathrm{~min}$ to separate kaolin. Then rarasaponin-kaolin was dried in oven for $24 \mathrm{~h}$, crushed and then was sieved using ASTM standard sieves to obtain 180-200 mesh particle size.

\subsection{Adsorption isotherm experiment}

The adsorption isotherm experiments were conducted in static mode at 303,318 and $333 \mathrm{~K}$. A known amount of kaolin or rarasaponin-kaolin $(0.1-1 \mathrm{~g})$ was added to a series of $100 \mathrm{~mL}$ Erlenmeyer flasks containing $50 \mathrm{~mL}$ of $800 \mathrm{ppm}$ MG solution. The Erlenmeyer flask was then removed to shaking water bath and shaken at $200 \mathrm{rpm}$ for $3 \mathrm{~h}$ at a desired temperature. After reaching equilibrium, the solution was centrifuged at $4500 \mathrm{rpm}$ for $5 \mathrm{~min}$ to separate the adsorbent from the solutions. The dye concentrations were determined using UV-spectrophotometer at $\lambda_{\max }=616.4 \mathrm{~nm}$, using a standard calibration graph. All experiments were carried out in triplicate.

The amount of dye adsorbed was calculated using formula $q_{\mathrm{e}}=\left(C_{0}-C_{\mathrm{e}}\right) \frac{V}{m}$ where $C_{0}$ and $C_{\mathrm{e}}$ are the initial and equilibrium concentrations $(\mathrm{mg} / \mathrm{L})$ of dye, respectively, $m$ is the adsorbent mass $(\mathrm{g})$ and $V$ is volume of the solution (L).

\subsection{Adsorption kinetic experiment}

In adsorption kinetic study, $0.5 \mathrm{~g}$ of kaolin or rarasaponin-kaolin was added in $50 \mathrm{~mL}$ of $800 \mathrm{ppm}$ MG solution at 303,318 and $333 \mathrm{~K}$. At certain time interval, MG concentrations were measured using UV-spectrophotometer at $\lambda_{\max }=616.4 \mathrm{~nm}$, using a standard calibration graph. All experiments were carried out in triplicate.

\section{Results and discussion}

\subsection{Adsorbent characterization}

The XRD spectra for kaolin and rarasaponin-kaolin are depicted in Fig. 1. The basal spacing of kaolin and rarasaponin-kaolin was calculated based on Braggs diffraction equation $\lambda=2 d \sin \theta$, where $\lambda$ is wavelength, $d$ is basal spacing (interlamelar spacing) and $\theta$ is the angle, $2 \theta$ is inversely proportional to $d$. The XRD spectra show that the angle of diffraction (2 $\theta)$ of 


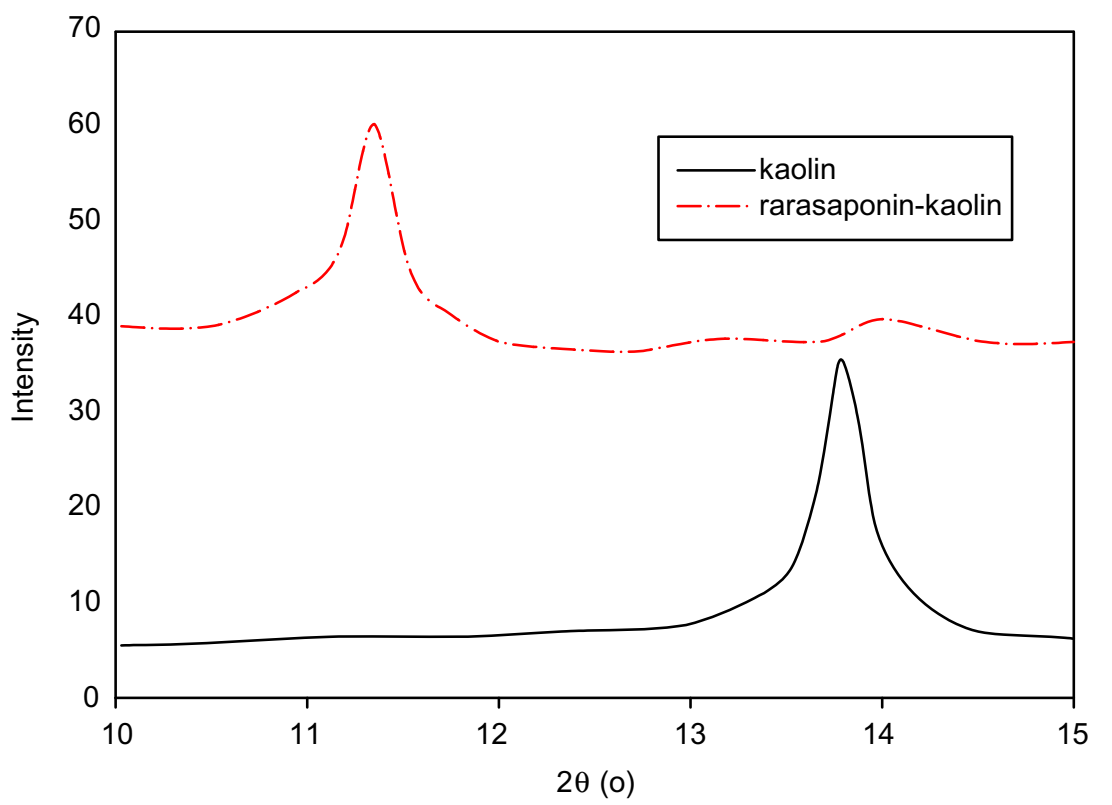

Fig. 1. XRD spectra for kaolin and rarasaponin-kaolin.

kaolin is $13.8272^{\circ}$ and rarasaponin-kaolin is $11.3419^{\circ}$. These angles of diffraction correspond to basal spacing of 6.3992 for kaolin and 7.7952 for rarasaponin-kaolin. The increase of basal spacing of rarasaponin-bentonite is possibly due to the intercalation of rarasaponin molecules into interlamelar spacing of kaolin.

The chemical composition of adsorbents was determined using XRF analysis. Kaolin contains $15.1 \%$ $\mathrm{Al}_{2} \mathrm{O}_{3} ; 67.5 \% \quad \mathrm{SiO}_{2} ; 1.13 \% \quad \mathrm{~K}_{2} \mathrm{O} ; 6.12 \% \quad \mathrm{CaO} ; 0.47 \%$ $\mathrm{TiO}_{2} ; 0.04 \% \mathrm{MnO} ; 8.86 \% \mathrm{Fe}_{2} \mathrm{O}_{3} ; 0.1 \% \mathrm{BaO}$ and $0.649 \%$ of other substances. After modification, the chemical composition of rarasaponin-kaolin: $13.9 \% \mathrm{Al}_{2} \mathrm{O}_{3} ; 66.2 \%$ $\mathrm{SiO}_{2} ; 1.37 \% \mathrm{~K}_{2} \mathrm{O} ; 4.39 \% \mathrm{CaO} ; 0.43 \% \mathrm{TiO}_{2} ; 0.04 \% \mathrm{MnO}$; $8.66 \% \mathrm{Fe}_{2} \mathrm{O}_{3} ; 0.14 \% \mathrm{BaO}$ and $4.931 \%$ of other substances. The change of chemical composition of kaolin is due to the presence of rarasaponin molecules in interlamelar spacing of kaolin.

The surface functional groups of kaolin and rarasaponin-kaolin were characterized using FTIR analysis. FTIR spectra for adsorbents before and after adsorption are depicted in Fig. 2. For easy reference, the wave numbers of each functional group present in both adsorbent are also summarized in Table 1. Significant difference of the peaks detected for rarasaponinkaolin and kaolin before adsorption is in wave numbers 2,900, 1,400 and $1,700 \mathrm{~cm}^{-1}$, which are $\mathrm{C}-\mathrm{H}$ stretching, $\mathrm{C}-\mathrm{H}$ bending and $\mathrm{C}=\mathrm{O}$ stretching, respectively. These functional groups belong to carbon chain and carbonyl functional groups of rarasaponin. The presence of these functional groups is strong indication that intercalation of rarasaponin molecules occurred during modification process. After the adsorption process, the peaks at about 2,900 and $1,400 \mathrm{~cm}^{-1}$ belong to carbonic structure of the dye which were observed in both adsorbents. The peak of $\mathrm{C}-\mathrm{N}$ stretch of MG structure was also observed at wave number around $1100 \mathrm{~cm}^{-1}$.

\subsection{Adsorption isotherm study}

Adsorption process is important for separation and purification of different kind of products in process industry. Different kinds of adsorption models which were initially developed for gas phase adsorption in principle, can also be used for liquid phase adsorption system. The most widely used isotherms to correlate the adsorption equation in the liquid phase are Langmuir and Freundlich. Other isotherms that are often used to correlate the liquid phase adsorption equilibria are Sip and Toth equation.

Langmuir model was developed based on simple assumptions [47]. The mathematical form of Langmuir model is as follow

$q_{\mathrm{L}_{\mathrm{e}}}=q_{\mathrm{L}_{\max }}\left(\frac{K_{\mathrm{L}} C_{\mathrm{e}}}{1+K_{\mathrm{L}} C_{\mathrm{e}}}\right)$

where $q_{\mathrm{L}_{\max }}$ is the maximum amount of adsorbate adsorbed on the adsorbent surface $(\mathrm{mmol} / \mathrm{g}) ; K_{\mathrm{L}}$ is the Langmuir constant $(\mathrm{L} / \mathrm{mmol}) ; q_{\mathrm{L}_{\mathrm{e}}}$ is the amount of adsorbed dye per unit weight of adsorbent $(\mathrm{mmol} / \mathrm{g})$ and $C_{\mathrm{e}}(\mathrm{mmol} / \mathrm{L})$ is the equilibrium concentration. 


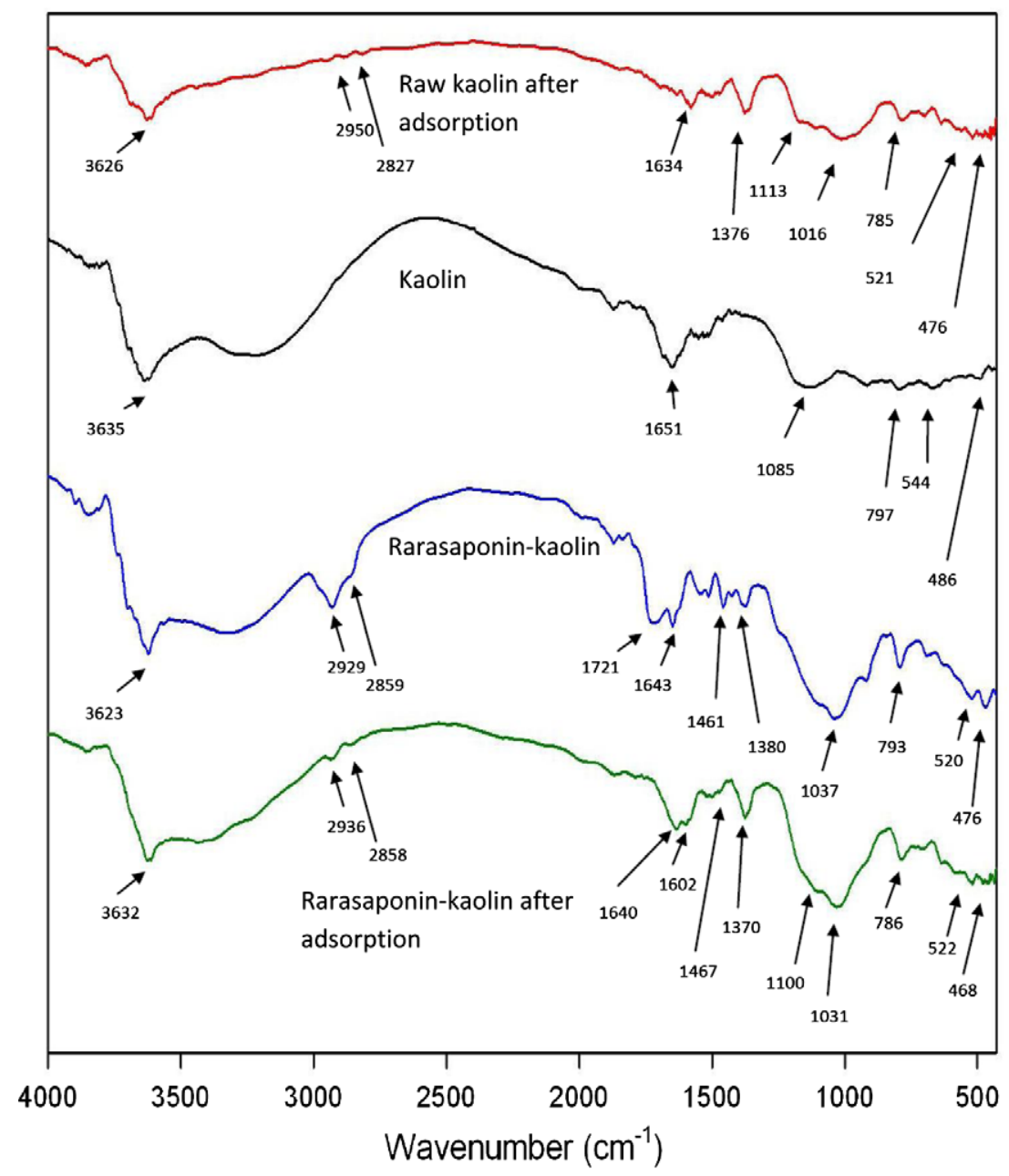

Fig. 2. FTIR spectra of kaolin after adsorption, kaolin before adsorption, rarasaponin-kaolin before adsorption and rarasaponin-kaolin after adsorption.

Experimental adsorption equilibrium data are often collected at various temperatures; the temperature dependent forms of Langmuir equation can be written as follow

$q_{\mathrm{L}_{\max }}=q_{\mathrm{L}_{\max }}^{0} \exp \left(\delta\left(T_{0}-T\right)\right)$

$K_{\mathrm{L}}=K_{\mathrm{L}_{0}} \exp \left[\frac{-E}{R T_{0}}\left(\frac{T_{0}}{T}-1\right)\right]$

here $q_{\mathrm{L}_{\max }}^{0}$ is the maximum Langmuir adsorption capacity at reference temperature $(\mathrm{mmol} / \mathrm{g}), \delta$ is the temperature expansion coefficient of the adsorbate $\left(\mathrm{K}^{-1}\right), K_{\mathrm{L}_{0}}$ is the Langmuir constant at reference temperature $(\mathrm{L} / \mathrm{mmol}), E$ is the heat of adsorption $(\mathrm{kJ})$ and $T_{0}$ is the reference temperature $(\mathrm{K})[48,49]$.

Freundlich model was developed based on assumption that adsorbent having heterogeneous surfaces. The main drawback of this model is that it is only applicable at moderate range of concentration [48]. The Freundlich equation has the form

$$
q_{\mathrm{Fr}_{\mathrm{e}}}=K_{\mathrm{Fr}} C_{\mathrm{e}}^{1 / n}
$$

the temperature dependent forms of Freundlich model are

$K_{\mathrm{Fr}}=K_{\mathrm{Fr}_{0}} \exp \left[\frac{-\alpha R T}{A_{0}}\right]$

$\frac{1}{n}=\frac{R T}{A_{0}}$

where $q_{\mathrm{Fr}_{\mathrm{e}}}$ is the amount of adsorbed dye per unit weight of adsorbent $(\mathrm{mmol} / \mathrm{g}) ; K_{\mathrm{Fr}}$ is the Freundlich adsorption capacity $(\mathrm{mmol} / \mathrm{g})(\mathrm{L} / \mathrm{mmol})^{-n} ; n$ is the heterogeneity of the system; $A_{0}$ is a constant and $K_{\mathrm{Fr}_{0}}$ is the adsorption capacity at reference temperature $T_{0}$. 
Table 1

The functional groups present in adsorbents

\begin{tabular}{lllll}
\hline & $\begin{array}{l}\text { Raw } \\
\text { kaolin }\end{array}$ & $\begin{array}{l}\text { Rarasaponin- } \\
\text { kaolin }\end{array}$ & $\begin{array}{l}\text { Raw kaolin after } \\
\text { adsorption }\end{array}$ & $\begin{array}{l}\text { Rarasaponin-kaolin after } \\
\text { adsorption }\end{array}$ \\
\hline Al(Mg)-OH stretching & 3,635 & 3,623 & 3,626 & 3,632 \\
H-O-H stretching & 3,596 & 3,539 & 3,532 & 3,535 \\
C-H stretching & - & 2,929 & 2,950 & 2,936 \\
C-H stretching & - & 2,859 & 2,827 & 2,858 \\
C=O stretching & - & 1,721 & - & 1,640 \\
H-O-H bending & 1,651 & 1,643 & 1,634 & 1,602 \\
C-H bending & - & 1,$461 ; 1,380$ & 1,376 & 1,370 \\
C-N stretching & - & - & 1,113 & 1,100 \\
Si-O-Si stretching & 1,085 & 1,037 & 1,016 & 1,031 \\
Si-O stretching of silica & 783,797 & 793 & 785 & 786 \\
$\quad$ quartz & & & 521 & 522 \\
Al-Si-O bending & 544 & 520 & 476 & 468 \\
Si-O-Si bending & 486 & 467,476 & & 5 \\
\hline
\end{tabular}

Sips isotherm is a combination of Freundlich and Langmuir equation $[48,50]$. Sips equation has the following form

$q_{\mathrm{S}_{\mathrm{e}}}=\frac{q_{\mathrm{S}_{\max }}\left(K_{\mathrm{s}} C_{\mathrm{e}}\right)^{1 / n}}{1+\left(K_{\mathrm{s}} C_{\mathrm{e}}\right)^{1 / n}}$

with its temperature dependent forms as follows:

$q_{\mathrm{S}_{\max }}=q_{\mathrm{S}_{\max }}^{0} \exp \left(\delta\left(T_{0}-T\right)\right)$

$K_{\mathrm{s}}=K_{\mathrm{s}_{0}} \exp \left[\frac{-E}{R T_{0}}\left(\frac{T_{0}}{T}-1\right)\right]$

$n=\frac{1}{\frac{1}{n_{0}}+\eta\left(1-\frac{T_{0}}{T}\right)}$

where $q_{\mathrm{S}_{\max }}$ is the maximum amount of adsorbate adsorbed on the adsorbent surface $(\mathrm{mmol} / \mathrm{g}) ; K_{\mathrm{s}}$ is the Sips adsorption affinity constant $(\mathrm{mmol} / \mathrm{L})^{1 / n} ; n$ is the heterogeneity of the system; $q_{\mathrm{S}_{\mathrm{e}}}$ is the amount of adsorbed dye per unit weight of adsorbent $(\mathrm{mmol} / \mathrm{g})$; $q_{\mathrm{S}_{\max }}^{0}$ is the maximum Sips adsorption capacity at reference temperature $(\mathrm{mmol} / \mathrm{g}) ; \delta$ is the temperature expansion coefficient of the adsorbate $\left(\mathrm{K}^{-1}\right), K_{\mathrm{s}_{0}}$ is the Sips constant at reference temperature $(\mathrm{mmol} / \mathrm{L})^{1 / n} ; E$ is the heat of adsorption $(\mathrm{kJ}) ; T_{0}$ is the reference temperature (K); $\eta$ is a constant; and $n_{0}$ is the heterogeneity of the system at reference temperature.

Another empirical equation also widely used to correlate the adsorption equilibria is Toth equation. This equation describes well many systems with sub-monolayer coverage [48], and it has the following form:

$q_{\mathrm{T}_{\mathrm{e}}}=\frac{q_{\mathrm{T}_{\max }} C_{\mathrm{e}}}{\left(K_{\mathrm{T}}+C_{\mathrm{e}}^{n}\right)^{1 / n}}$

like the other equations described previously, Toth equation also possesses the temperature dependent of equilibrium parameters as follows

$$
\begin{aligned}
& q_{\mathrm{T}_{\max }}=q_{\mathrm{T}_{\max }}^{0} \exp \left(\delta\left(T_{0}-T\right)\right) \\
& K_{\mathrm{T}}=K_{\mathrm{T}_{0}} \exp \left[\frac{-E}{R T_{0}}\left(\frac{T_{0}}{T}-1\right)\right] \\
& n=n_{0}+\eta\left(1-\frac{T_{0}}{T}\right)
\end{aligned}
$$

where $q_{T_{\max }}$ is the maximum amount of adsorbate adsorbed on the adsorbent surface $(\mathrm{mmol} / \mathrm{g}) ; K_{\mathrm{T}}$ is the Toth constant $(\mathrm{mmol} / \mathrm{L})^{n} ; n$ is the heterogeneity of the system; $q_{\mathrm{T}_{\mathrm{e}}}$ is the amount of adsorbed dye per unit weight of adsorbent $(\mathrm{mmol} / \mathrm{g}) ; C_{\mathrm{e}}(\mathrm{mmol} / \mathrm{L})$ is adsorbate equilibrium concentration; $q_{\mathrm{T}_{\max }}^{0}$ is the maximum Toth adsorption capacity at reference temperature $(\mathrm{mmol} / \mathrm{g}), \delta$ is the temperature expansion coefficient of the adsorbate $\left(\mathrm{K}^{-1}\right), K_{\mathrm{T}_{0}}$ is the Toth constant at reference temperature $(\mathrm{mmol} / \mathrm{L})^{n}, E$ is the isosteric heat of adsorption (kJ); $T_{0}$ is the reference temperature (K); $\eta$ is a constant; and $n_{0}$ is the heterogeneity of the system at reference temperature.

The parameters of the models were obtained by non-linear least squares fit of the isotherm models to 
the experimental adsorption equilibria. The calculations were conducted for all temperatures of the adsorption equilibria simultaneously by using the following Sum Square of Error (SSE) as the objective function to be minimized

$\mathrm{SSE}=\left(\frac{\left(\sum\left(q_{e(\exp )}-q_{e(\mathrm{calc})}\right)^{2}\right)}{N}\right)^{1 / 2}$

where $q_{\mathrm{e}(\exp )}$ is the experimental amount of dye adsorbed, $q_{\mathrm{e} \text { (calc) }}$ is the calculated amount of dye adsorbed using the isotherm model and $N$ is the number of experimental data.

Figs. 3 and 4 show the adsorption experimental equilibria data of MG onto kaolin and rarasaponinkaolin and those calculated using Langmuir, Freundlich, Sips and Toth equations. The symbols represent the adsorption experimental data, while the solid lines represent the fitted models. The optimum parameters obtained from the above fitting procedure are summa-
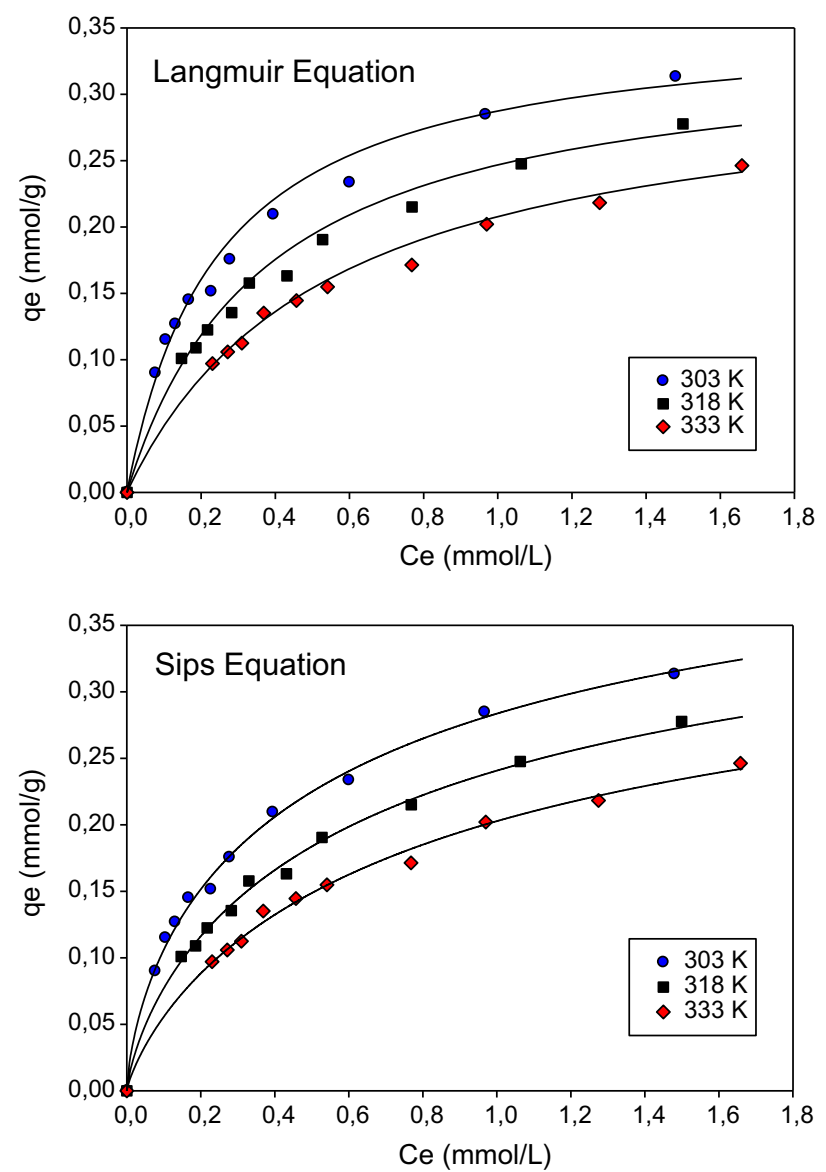

rized in Table 2. From Figs. 3 and 4 , it can be seen that all the models can represent the adsorption experimental data well. However, to choose the correct isotherm which can represent the experimental adsorption data, we cannot just depend on visual representation of the models or just based on the value of SSE, we should examine further the physical meaning of each parameters involved in the models. The correct choice of the isotherm must be based on the consistency of physical meaning and reasonable value of the parameters.

As mentioned before, the Langmuir equation was developed based on three simple assumptions and in large number of adsorption studies, this model can represent the data better than other isotherm equations, also this model seems to represent the adsorption equilibrium data of MG onto kaolin and rarasaponin-kaolin. Before we decide the applicability of this model to represent our adsorption experimental data, we will discuss the physical meaning and consistency of the parameters. The parameter $q_{\mathrm{L}_{\max }}^{0}$ is
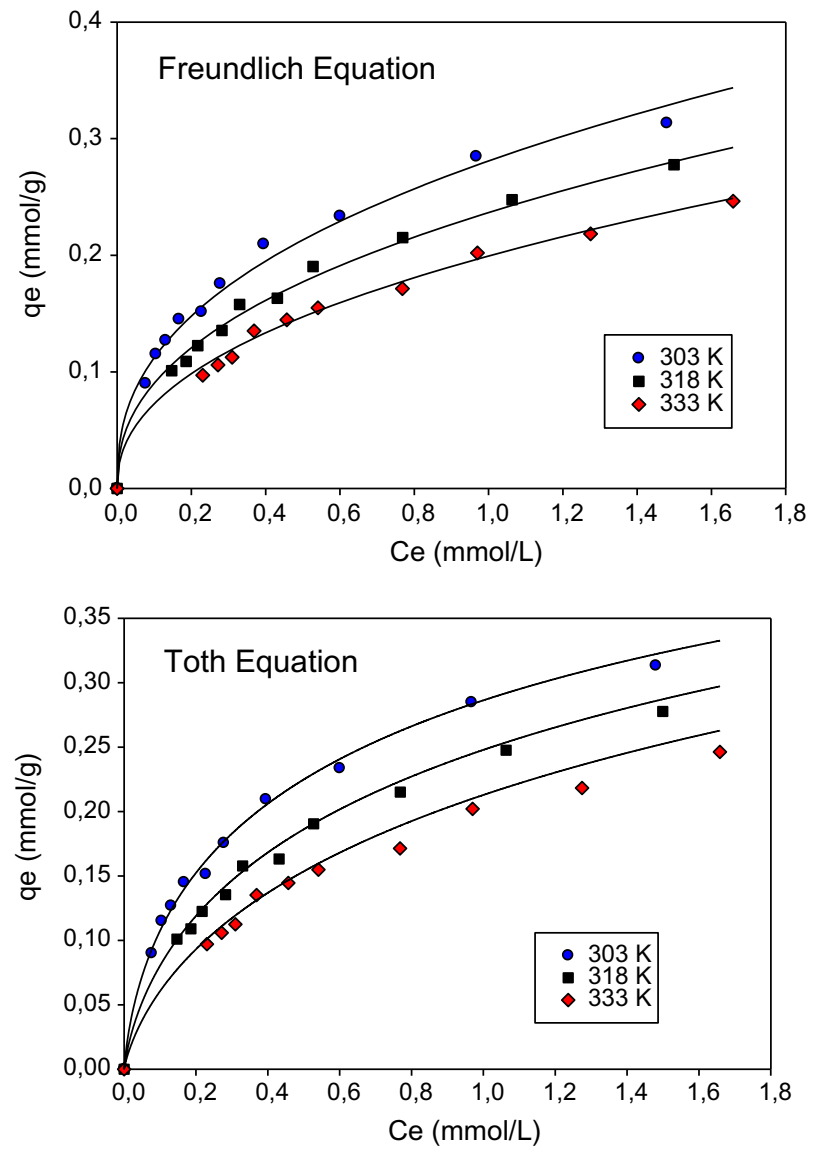

Fig. 3. Experimental adsorption equilibria data of MG onto kaolin and plots of adsorption models at various temperatures. 

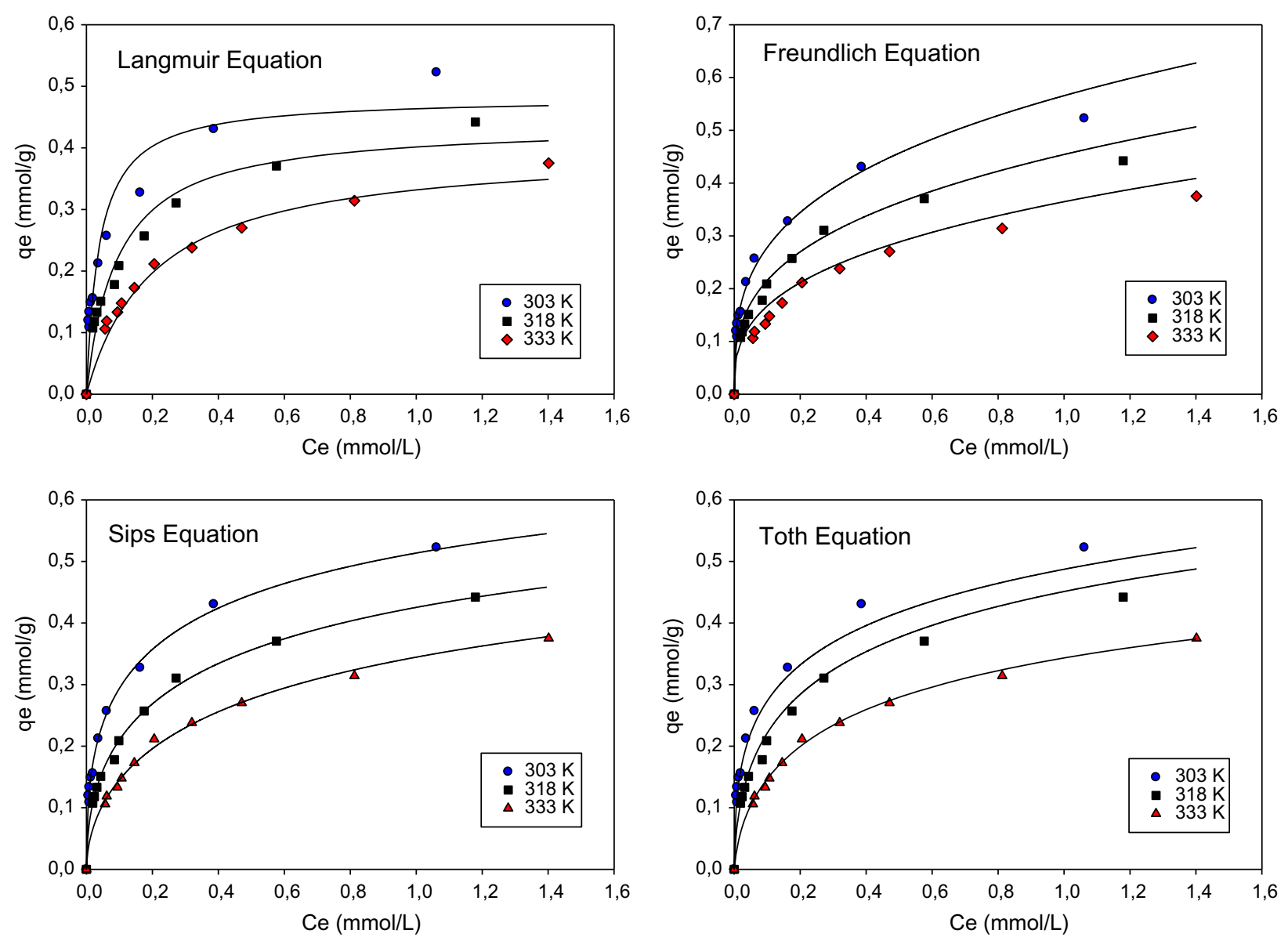

Fig. 4. Experimental adsorption equilibria data of MG onto rarasaponin-kaolin and plots of adsorption models at various temperatures.

the maximum Langmuir adsorption capacity at reference temperature $\left(25^{\circ} \mathrm{C}\right)$, and the values of this parameter for Kaolin and rarasaponin-kaolin are reasonable and consistent. The purpose of modification of Kaolin is to enhance its adsorption capability, and this phenomenon is caught by parameter $q_{\mathrm{L}_{\max }^{0}}^{0}$, the value of this parameter for rarasaponin-kaolin is higher than in Kaolin, strong indication that the modification of kaolin enhanced its adsorption capacity.

Parameter $\delta$ is the temperature expansion coefficient of the adsorbate, the value of this parameter is specific for a given component and independent of the type of adsorbent [49]. From Table 2, it can be seen that the fitted value of parameter $\delta$ by Langmuir model for kaolin and rarasaponin-kaolin is different. The values of parameter $\delta$ for kaolin and rarasaponinkaolin are $0.0038 / \mathrm{K}$ and $0.0062 / \mathrm{K}$, respectively. The difference in values of parameter $\delta$ for kaolin and rarasaponin-kaolin is an indication that the Langmuir parameter is not adequate for the system studied. In order to get better understanding, about the physical meaning of the Langmuir parameters, we will continue our discussion for the remaining fitted parameters.

Parameter $E$ in Langmuir equation is the heat of adsorption, invariant with the surface loading [48]. When the heat of adsorption increases, the adsorbed amount increases due to the higher energy barrier that adsorbed molecules have to overcome to diffuse back to the bulk liquid. During modification of kaolin using rarasaponin, some of the rarasaponin molecules intercalate to the interlayer spacing of kaolin and the insertion of the rarasaponin molecules increase the heterogeneity of the adsorbent. With the presence of another substance (rarasaponin) in the kaolin structure, other adsorption mechanisms also will occur, leading to the increase heat of adsorption. As depicted in Figs. 3 and 4, it is obvious that the adsorption of MG onto Kaolin and rarasaponin-kaolin is controlled by physical adsorption mechanism. In physical adsorption mechanism, the uptake of adsorbate decreases with increase in temperature. Physical 
Table 2

Fitted parameters of adsorption equations

\begin{tabular}{|c|c|c|c|}
\hline Isotherm & Parameters & Kaolin & Rarasaponin-kaolin \\
\hline \multirow[t]{5}{*}{ Langmuir } & $q_{\mathrm{L}_{\max }}^{0}(\mathrm{mmol} / \mathrm{g})$ & 0.365 & 0.497 \\
\hline & $\delta\left(\mathrm{K}^{-1}\right)$ & 0.0038 & 0.0062 \\
\hline & $E(\mathrm{~kJ} / \mathrm{mol})$ & 21.83 & 46.25 \\
\hline & $K_{\mathrm{L}_{0}}(\mathrm{~L} / \mathrm{mmol})$ & 4.392 & 34.534 \\
\hline & SSE & 0.006 & 0.005 \\
\hline \multirow[t]{3}{*}{ Freundlich } & $K_{\mathrm{F}_{0}}(\mathrm{mmol} / \mathrm{g})(\mathrm{L} / \mathrm{mmol})^{-n}$ & 8.974 & 47.582 \\
\hline & $\alpha / A_{0}$ & 0.0014 & 0.0018 \\
\hline & SSE & 0.0024 & 0.0067 \\
\hline \multirow[t]{7}{*}{ Sips } & $q_{\mathrm{S}_{\max }}^{0}(\mathrm{mmol} / \mathrm{g})$ & 0.509 & 0.919 \\
\hline & $\delta\left(\mathrm{K}^{-1}\right)$ & 0.0076 & 0.0079 \\
\hline & $K_{\mathrm{S}_{0}}(\mathrm{mmol} / \mathrm{L})^{1 / n}$ & 1.681 & 2.410 \\
\hline & $E(\mathrm{~kJ} / \mathrm{mol})$ & 10.01 & 21.72 \\
\hline & $n_{0}$ & 1.482 & 2.370 \\
\hline & $\eta$ & 1.314 & 1.405 \\
\hline & SSE & 0.0016 & 0.0017 \\
\hline \multirow[t]{7}{*}{ Toth } & $q_{\mathrm{T}_{\max }}^{0}(\mathrm{mmol} / \mathrm{g})$ & 0.709 & 1.956 \\
\hline & $\delta\left(\mathrm{K}^{-1}\right)$ & -0.0029 & 0.0271 \\
\hline & $K_{\mathrm{T}_{0}}(\mathrm{mmol} / \mathrm{L})^{n}$ & 0.419 & 0.253 \\
\hline & $E(\mathrm{~kJ} / \mathrm{mol})$ & 12.27 & 8.76 \\
\hline & $n_{0}$ & 0.407 & 0.151 \\
\hline & $\eta$ & -0.145 & 2.321 \\
\hline & SSE & 0.086 & 0.042 \\
\hline
\end{tabular}

adsorption processes usually have adsorption energies less than $40 \mathrm{~kJ} / \mathrm{mol}$, while higher energies $(40-800 \mathrm{~kJ} /$ mol) suggest chemisorptions. The fitted parameter $E$ for kaolin is reasonable and consistent with the physical meaning of this parameter, but not for rarasaponin-kaolin as seen in Table 2 . The value of fitted parameter $E$ for rarasaponin-kaolin suggests that the chemisorptions mechanism controls the process, a contradiction with the experimental data.

Parameter $K_{\mathrm{L}_{0}}$ is the Langmuir constant at reference temperature. This parameter is also called as the affinity constant, which measures how strong adsorbate molecules are attracted into surface of adsorbent [48]. When the affinity constant $K_{\mathrm{L}_{0}}$ is larger, the interaction of adsorbate molecules toward the adsorbent surface is stronger and the surface of adsorbent is covered with more adsorbate molecules. With the increase heterogeneity of the system, due to the insertion of rarasaponin molecules into interlayer structure of kaolin, the interaction of MG into rarasaponin-bentonite surface become stronger. This phenomenon was captured by the fitted parameter $K_{\mathrm{L}_{0}}$ in Langmuir model, consistent and reasonable values of Langmuir affinity constant are observed as indicated in Table 2 . The fitted affinity constant of Langmuir equation for rarasaponin-kaoilin is higher than kaolin. Even several parameters $\left(q_{\mathrm{L}_{\max }}^{0}\right.$ and $\left.K_{\mathrm{L}_{0}}\right)$ are reasonable and have consistent physical meaning, the failure of parameters $E$ and $\delta$ to give consistent physical meaning are indication that the Langmuir model is not adequate to correlate the adsorption experimental data of MG onto kaolin and rarasaponin-kaolin.

Similar to the Langmuir model, the fitted parameters $K_{\mathrm{Fr}_{0}}$ (Freundlich), (Sips model) and $q_{\mathrm{T}_{\max }^{0}}^{0}$ (Toth equation) represent the maximum adsorption capacity. Consistent and reasonable parameter values of maximum adsorption capacity were obtained for both Sips and Toth models, but not for Freundlich model as given in Table 2. Since the Freundlich equation fails to give reasonable value for the adsorption capacity parameter, it will not be included in further discussion. As expected, the fitted parameter $q_{\mathrm{S}_{\max }}^{0}$ (Sips model) and $q_{\mathrm{T}_{\max }}^{0}$ (Toth equation) for rarasaponin-kaolin are higher than kaolin. As mentioned before, the parameter $\delta$ is the temperature expansion coefficient of the adsorbate and its value 
must be positive and specific for a given component and does not depend on the type of adsorbent. The fitted parameter $\delta$ of Sips model for both kaolin and rarasaponin kaolin is essentially constant and of the order of $10^{-3} \mathrm{~K}^{-1}$, consistent with the value of many adsorbate [49]. Toth equation failed to give consistent and reasonable result of this fitted parameter as seen in Table 2.

The purpose of kaolin modification is to enhance its adsorption capacity. The adsorption capacity of rarasaponin-kaolin towards MG is higher than original kaolin. When the amount of MG uptake increases, the surface is covered more with MG molecules as a result of the stronger affinity of MG molecule towards the surface of rarasaponin-kaolin. The fitted parameter of adsorption affinity of Sips model obeys this phenomenon and the opposite behaviour was observed for Toth model as indicated in Table 2. As mentioned in previous paragraph, the increase in the amount of MG uptake causes the increase of heat of adsorption due to the higher energy barrier that adsorbed molecules have to overcome to diffuse back to the bulk liquid [48], therefore, the adsorption energy of MG onto rarasaponin-kaolin should be higher than the adsorption energy of MG onto kaolin. This phenomenon was caught by fitted parameter $E$ of Sips model, while the Toth equation failed to give consistent value of this parameter. These evidences clearly indicate that Toth model is not suitable for correlating the adsorption experimental data of MG onto kaolin or rarasaponin-kaolin.

The parameter $n_{0}$ in Sips model could be regarded as the parameter characterizing the system heterogeneity. If the value of $n_{0}$ is more deviate from unity, the system is more heterogeneous. The intercalation of rarasaponin molecules into kaolin structure increases the heterogeneity of the system and the fitted parameter $n_{0}$ of Sips model is consistent with the physical meaning of this parameter. Based on the evaluation, of the physical meaning of fitted parameters of each equation, it is clear that the Sips equation can represent the adsorption data better than the other equations.

\subsection{Adsorption kinetic study}

To properly design an adsorption system, additional information besides adsorption equilibria is needed and that necessary information is the adsorption kinetics [48,51]. Numerous kinetic models are available for the prediction of behaviour of kinetic experimental data. Most widely used models are pseudo-first-order [52] and pseudo-second-order [53].

Pseudo-first-order model is the earliest known model, describing the rate of sorption in the liquid phase system [51], and this model has the following form:

$$
\frac{\mathrm{d} q_{\mathrm{t}}}{\mathrm{d} t}=k_{1}\left(q_{\mathrm{e}}-q_{\mathrm{t}}\right)
$$

where $k_{1}$ is rate constant of pseudo-first-order reaction $\left(\min ^{-1}\right) ; q_{\mathrm{e}}$ is the amount of adsorbate adsorbed at equilibrium $(\mathrm{mmol} / \mathrm{g})$ and $q_{\mathrm{t}}$ is the amount of adsorbate adsorbed at certain time $(\mathrm{mmol} / \mathrm{g})$. Integration of Eq. (16) yield:

$q_{\mathrm{t}}=q_{\mathrm{e}}\left(1-\exp \left(-k_{1} t\right)\right)$

Pseudo-second-order model was developed by Blanchard et al. [53], to describe the kinetics of heavy metal removal by natural zeolites. This model is usually associated with the situation when the rate of direct adsorption/desorption process controls the overall sorption kinetics [51]. The mathematical form of the pseudo-second-order is

$\frac{\mathrm{d} q_{\mathrm{t}}}{\mathrm{d} t}=k_{2}\left(q_{\mathrm{e}}-q_{\mathrm{t}}\right)^{2}$

where $k_{2}$ is rate constant of pseudo-second-order model $\left(\mathrm{g} / \mathrm{mmol} \mathrm{min}^{-1}\right)$. Integration of Eq. (18) yield:

$q_{\mathrm{t}}=q_{\mathrm{e}}\left(\frac{q_{\mathrm{e}} k_{2} t}{1+q_{\mathrm{e}} k_{2} t}\right)$

The adsorption kinetic experimental data and the fitted model of pseudo-first and pseudo-second-order of MG onto kaolin and rarasaponin-kaolin are given in Figs. 5 and 6, respectively. The fitted parameters of pseudo-first and pseudo-second-order models are summarized in Table 3 for kaolin and Table 4 for rarasaponin-kaolin. Visually, both of these models can represent the experimental data well as indicated in Figs. 5 and 6 . However, the calculated values of $q_{\mathrm{e}}$ values from pseudo-second-order deviate quite large from experimental data. Pseudo-first-order gives reasonable values of the fitted parameters as indicated in Tables 3 and 4. Better fitted values obtained for pseudo-first-order than pseudo-second-order also an indication that physical adsorption mechanism was more dominant than chemisorptions. As mentioned by Plazinski et al. [51], the pseudo-second-order is associated with the situation when the rate of direct adsorption/desorption process is seen as a kind of chemical reaction; while the pseudo-first-order was developed based on the assumption that overall rate of sorption was determined by the rate of direct solute transfer from the solution to the adsorbed phase 
(a)

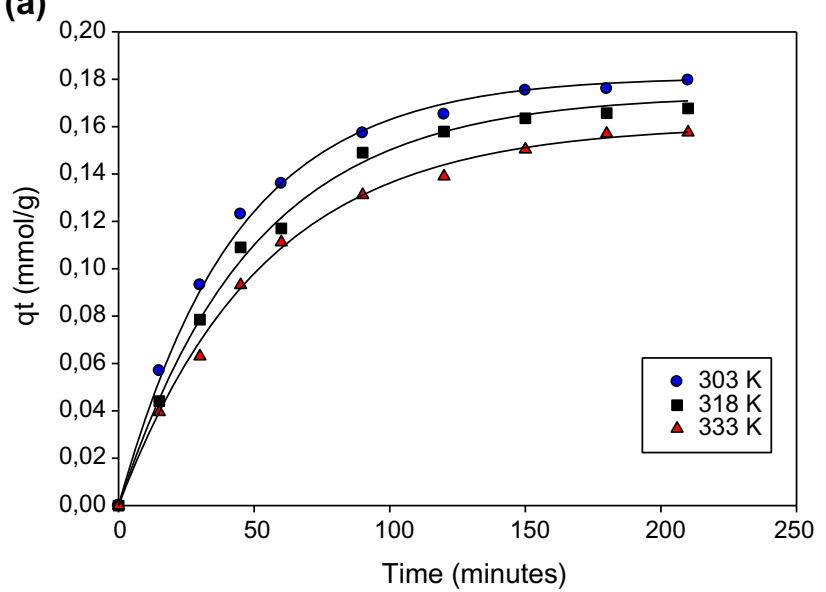

(b)

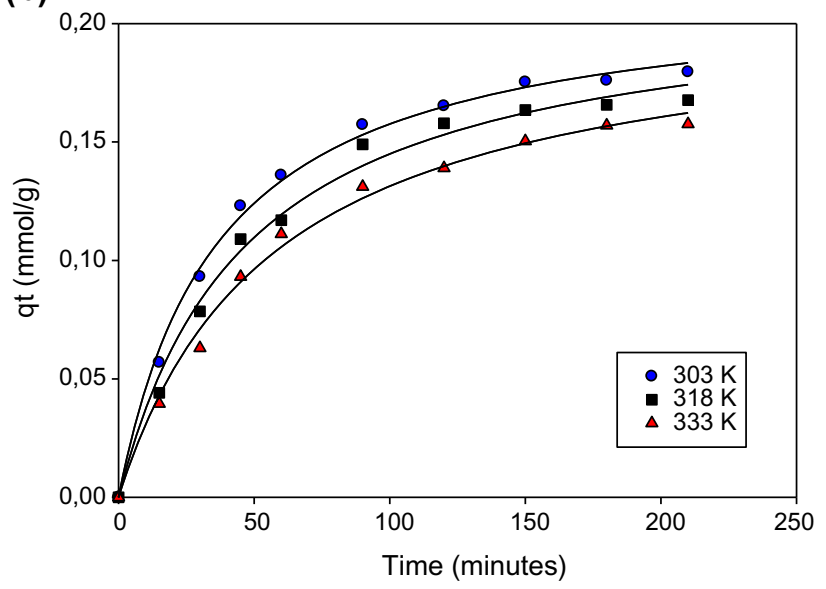

Fig. 5. The adsorption kinetic experimental data of MG onto kaolin and model fitted of (a) pseudo-first-order and (b) pseudo-second-order.

(physical interaction between adsorbate and adsorbent).

\subsection{Adsorption thermodynamic}

To get a complete feature of the adsorption MG onto kaolin and rarasaponin-kaolin, thermodynamic study was also conducted. Thermodynamic properties like standard Gibb's free energy change $\left(\Delta G^{0}\right)$, stan- (a)

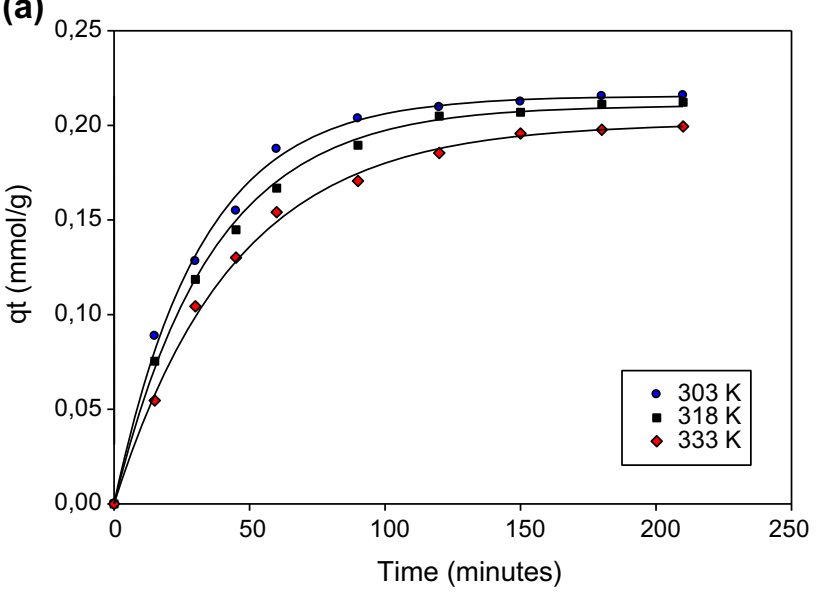

(b)

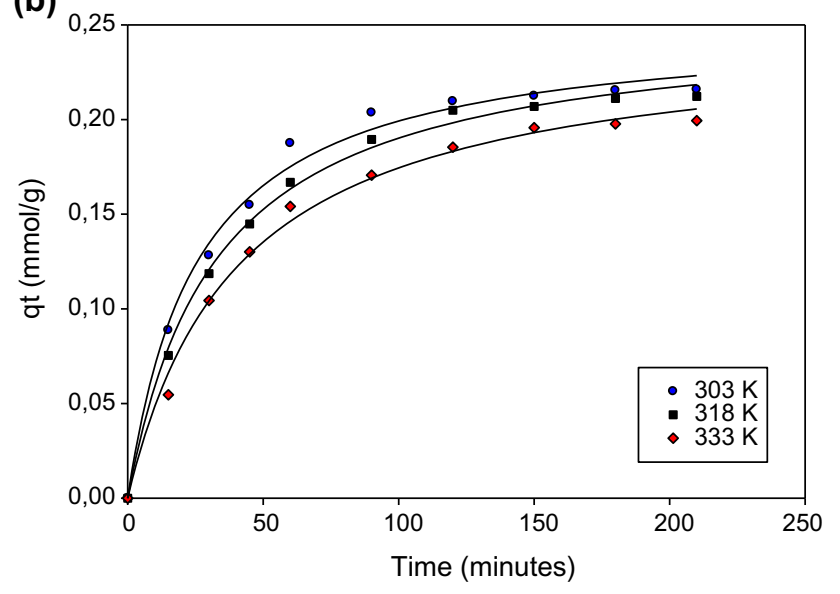

Fig. 6. The adsorption kinetic experimental data of MG onto rarasaponin-kaolin and model fitted of (a) pseudofirst-order and (b) pseudo-second-order.

dard enthalpy change $\left(\Delta H^{0}\right)$ and standard entropy change $\left(\Delta S^{0}\right)$ of the adsorption of MG onto kaolin and rarasaponin-kaolin were investigated. The standard Gibbs free energy $\left(\Delta G^{0}\right)$ at a constant temperature can be calculated using the following formula

$\Delta \mathrm{G}^{0}=-R T \ln K_{\mathrm{d}}$

where $K_{\mathrm{d}}$ is thermodynamic distribution coefficient. The values of $K_{\mathrm{d}}$ were obtained by plotting $q_{\mathrm{e}}$ as $x$ -

Table 3

The adsorption kinetic parameters of MG onto kaolin

\begin{tabular}{|c|c|c|c|c|c|c|c|}
\hline \multirow[t]{2}{*}{ Temperature } & \multirow[t]{2}{*}{$q_{\exp }(\mathrm{mmol} / \mathrm{g})$} & \multicolumn{3}{|c|}{ Pseudo-first-order } & \multicolumn{3}{|c|}{ Pseudo-second-order } \\
\hline & & $q_{\mathrm{e}}(\mathrm{mmol} / \mathrm{g})$ & $k_{1}\left(\min ^{-1}\right)$ & $r^{2}$ & $q_{\mathrm{e}}(\mathrm{mmol} / \mathrm{g})$ & $k_{2}\left(\mathrm{~g} \mathrm{mmol}^{-1} \mathrm{~min}^{-1}\right)$ & $r^{2}$ \\
\hline $30^{\circ} \mathrm{C}$ & 0.1796 & 0.1810 & 0.0231 & 0.9987 & 0.2156 & 0.1260 & 0.9964 \\
\hline $45^{\circ} \mathrm{C}$ & 0.1677 & 0.1734 & 0.0201 & 0.9975 & 0.2134 & 0.0991 & 0.9913 \\
\hline $60^{\circ} \mathrm{C}$ & 0.1576 & 0.1607 & 0.0188 & 0.9974 & 0.2065 & 0.0845 & 0.9941 \\
\hline
\end{tabular}


Table 4

The adsorption kinetic parameters of MG onto rarasaponin-kaolin

\begin{tabular}{|c|c|c|c|c|c|c|c|}
\hline \multirow[t]{2}{*}{ Temperature } & \multirow[t]{2}{*}{$q_{\exp }(\mathrm{mmol} / \mathrm{g})$} & \multicolumn{3}{|c|}{ Pseudo-first-order } & \multicolumn{3}{|c|}{ Pseudo-second-order } \\
\hline & & $\overline{q_{\mathrm{e}}(\mathrm{mmol} / \mathrm{g})}$ & $k_{1}\left(\min ^{-1}\right)$ & $r^{2}$ & $\overline{q_{\mathrm{e}}(\mathrm{mmol} / \mathrm{g})}$ & $k_{2}\left(\mathrm{~g} \mathrm{mmol} \mathrm{min}^{-1}\right)$ & $r^{2}$ \\
\hline $30^{\circ} \mathrm{C}$ & 0.2158 & 0.2155 & 0.0313 & 0.9964 & 0.2507 & 0.1541 & 0.9916 \\
\hline $45^{\circ} \mathrm{C}$ & 0.2122 & 0.2106 & 0.0276 & 0.9985 & 0.2524 & 0.1210 & 0.9968 \\
\hline $60^{\circ} \mathrm{C}$ & 0.1994 & 0.2012 & 0.0225 & 0.9981 & 0.2454 & 0.1001 & 0.9939 \\
\hline
\end{tabular}

Table 5

Thermodynamic parameters of MG adsorption onto kaolin and rarasaponin-kaolin

\begin{tabular}{|c|c|c|c|c|c|c|}
\hline \multirow[t]{2}{*}{$T(\mathrm{~K})$} & \multicolumn{3}{|l|}{ Kaolin } & \multicolumn{3}{|c|}{ Rarasaponin-kaolin } \\
\hline & $\Delta H^{0}(\mathrm{~kJ} / \mathrm{mol})$ & $\Delta S^{0}(\mathrm{~kJ} / \mathrm{mol} . / \mathrm{K})$ & $\overline{\Delta \mathrm{i}^{0}(\mathrm{~kJ} / \mathrm{mol})}$ & $\Delta H^{0}(\mathrm{~kJ} / \mathrm{mol})$ & $\Delta S^{0}(\mathrm{~kJ} / \mathrm{mol} . \mathrm{K})$ & $\Delta G^{0}(\mathrm{~kJ} / \mathrm{mol})$ \\
\hline 303 & -29.81 & -0.09 & -2.25 & -61.62 & -0.17 & -9.12 \\
\hline 318 & & & -0.88 & & & -6.52 \\
\hline 333 & & & 0.48 & & & -3.92 \\
\hline
\end{tabular}

axis, $\ln \left(q_{\mathrm{e}} / C_{\mathrm{e}}\right)$ as $y$-axis and the intercept is the value of $\ln K_{\mathrm{d}}$. Based on van't Hoff equation, standard enthalpy change $\left(\Delta H^{0}\right)$ and standard entropy change $\left(\Delta S^{0}\right)$ are correlated to the thermodynamic distribution coefficient $\left(K_{\mathrm{d}}\right)$

$\frac{\Delta H^{0}}{R T}-\frac{\Delta S^{0}}{R}=-\ln K_{\mathrm{d}}$

by plotting $1 / T$ vs. $-\ln K_{\mathrm{d}}$, the values of $\Delta H^{0}$ and $\Delta S^{0}$ can be obtained. The thermodynamic parameters obtained from Eqs. (20) and (21) are summarized in Table 5. $\Delta H^{0}$ values for both kaolin and rarasaponinkaolin are negative indicating that the adsorption of MG onto both adsorbents is exothermic and the increase in temperature will decrease the uptake of the adsorbate. The $\Delta S^{0}$ for kaolin and rarasaponinkaolin are both negative due to interaction between adsorbate and adsorbent that made the system less disorder. $\Delta G^{0}$ is the most important parameter to determine whether the adsorption occurs spontaneously. The negative value of $\Delta G^{0}$ indicates that the adsorption of MG onto kaolin and rarasaponin-kaolin occurrs spontaneously. The increase of $\Delta G^{0}$ value with temperature indicates that the adsorption of $\mathrm{MG}$ is less favourable at high temperature.

\section{Conclusion}

Modification of Kaolin using natural surfactant rarasaponin increases the adsorption capability of kaolin. The adsorption experimental data were correlated using Langmuir, Freundlich, Sips and Toth equations.
Sips model gave consistent and reasonable values of the fitted parameters. The pseudo-first-order gave better correlation for the adsorption kinetic of MG onto kaolin and rarasaponin-kaolin. Thermodynamic properties like standard Gibb's free energy change $\left(\Delta G^{0}\right)$, standard enthalpy change $\left(\Delta H^{0}\right)$ and standard entropy change $\left(\Delta S^{0}\right)$ of the adsorption of MG onto kaolin and rarasaponin-kaolin were obtained in this study.

\section{References}

[1] P. Nigam, G. Armour, I.M. Banat, D. Singh, D. Singh, R. Marchant, Physical removal of textile dyes and solid state fermentation of dye adsorbed agricultural residues, Bioresour. Technol. 72 (2000) 219-226.

[2] S.J. Allen, Q. Gan, R. Matthews, P.A. Johnson, Kinetic modeling of the adsorption of basic dyes by kudzu, J. Colloid Interf. Sci. 286 (2005) 101-109.

[3] G. Crini, H.N. Peindy, F. Gimbert, C. Robert, Removal of C.I. Basic Green 4 (Malachite Green) from aqueous solution by adsorption using cyclodextrin based adsorbent: Kinetic and equilibrium studies, Sep. Purif. Technol. 53 (2007) 97-110.

[4] N. Kannan, M.M. Sundaram, Kinetics and mechanism of removal of methylene blue by adsorption on various carbons-a comparative study, Dyes Pigments 51 (2001) 25-40.

[5] V. Vimonsesa, S. Lei, B. Jin, C.W.K. Chow, C. Saint, Kinetic study and equilibrium isotherm analysis of Congo Red adsorption by clay materials, Microporous Mesoporous Mater. 115 (2008) 234-246.

[6] S. Chowdhury, R. Mishra, P. Saha, Adsorption thermodynamics, kinetics and isosteric heat of adsorption of malachite green onto chemically modified rice husk, Desalination 265 (2010) 159-168.

[7] P. Saha, S. Chowdhury, S. Gupta, I. Kumar, R. Kumar, Assessment on the removal of malachite green using tamarind fruit shell as biosorbent, Clean: Soil, Air, Water 38 (2010) 437-445.

[8] A. Srivastava, R. Sinha, D. Roy, Toxicological effects of malachite green, J. Am. Coll. Toxicol. 66 (2004) 319-329. 
[9] S. Chowdhury, P. Saha, Sea shell powder as a new adsorbent to remove Basic Green 4 (malachite green) from aqueous solutions: Equilibrium, kinetic and thermodynamic studies, Chem. Eng. J. 164 (2010) 168-177.

[10] S.J. Culp, F.A. Beland, Malachite green: A toxicological review, J. Am. Coll. Toxicol. 15 (1996) 219-238.

[11] S.J. Culp, L.R. Blankenship, D.F. Kusewitt, D.R. Doerge, L.T. Mulligan, F.A. Beland, Toxicity and metabolism of malachite green and leucomalachite green during short-term feeding to Fischer 344 rats and $\mathrm{B} 6 \mathrm{C} 3 \mathrm{~F}(1)$ mice, Chem.-Biol. Interact. 122 (1999) 153-170.

[12] S. Singh, M. Das, S.K. Khanna, Biodegradation of malachite green and rhodamine-b by cecal microflora of rats, Biochem. Biophys. Res. Commun. 200 (1994) 1544-1550.

[13] V.K. Gupta, A. Mittal, L. Krishnan, V. Gajbe, Adsorption kinetics and column operations for the removal and recovery of malachite green from wastewater using bottom ash, Sep. Purif. Technol. 40 (2004) 87-96.

[14] K.V. Kumar, S. Sivanesan, V. Ramamurthi, Adsorption of malachite green onto Pithophora sp., a fresh water algae: Equilibrium and kinetic modelling, Process Biochem. 40 (2005) 2865-2872.

[15] I.D. Mall, V.C. Srivastava, N.K. Agarwal, I.M. Mishra, Adsorptive removal of malachite green dye from aqueous solution by bagasse fly ash and activated carbon-kinetic study and equilibrium isotherm analyses, Colloids Surf. A 264 (2005) 17-28.

[16] S.S. Tahir, N. Rauf, Removal of a cationic dye from aqueous solutions by adsorption onto bentonite clay, Chemosphere 63 (2006) 1842-1848.

[17] A.S. Mahmoud, A.E. Ghaly, M.S. Brooks, Removal of dye from textile wastewater using plant oils under different $\mathrm{pH}$ and temperature conditions, Am. J. Environ. Sci. 3 (2007) 205-218.

[18] A.B.C. Alvares, C. Diaper, S.A. Parsons, Partial oxidation by ozone to remove recalcitrance from wastewaters-a review, Environ. Technol. 22 (2001) 409-427.

[19] A.R.T. Bagha, H. Nikkar, N.M. Mahmoodi, M. Markazi, F.M. Menger, The sorption of cationic dyes onto kaolin: Kinetic, isotherm and thermodynamic studies, Desalination 266 (2011) 274-280.

[20] G. Crini, Non-conventional low-cost adsorbents for dye removal: A review, Bioresour. Technol. 97 (2006) 1061-1085.

[21] E. Forgacs, T. Cserháti, G. Oros, Removal of synthetic dyes from wastewaters: A review, Environ. Int. 30 (2004) 953-971.

[22] P.R. Gogate, A.B. Pandit, A review of imperative technologies for wastewater treatment II-hybrid methods, Adv. Environ. Res. 8 (2004) 553-597.

[23] T. Robinson, G. McMullan, R. Marchant, P. Nigam, Remediation of dyes in textile effluent: A critical review on current treatment technologies with a proposed alternative, Bioresour. Technol. 77 (2001) 247-255.

[24] P.C. Vandevivere, R. Bianchi, W. Verstraete, Treatment and reuse of wastewater from the textile wet-processing industry: Review of emerging technologies, J. Chem. Technol. Biotechnol. 72 (1998) 289-302

[25] V.K. Gupta, I. Ali, Adsorbents for water treatment: Lowcost alternatives to carbon, In: A. Hubbard (Ed), Encyclopedia of Surface and Colloid Science, vol. 1, Marcel Dekker, New York, NY, 2002, pp. 136-166.

[26] G. Mckay, S.J. Allen, I.F. Meconney, M.S. Ottrburn, Transport processes in the sorption of coloured ions by peat particles, J. Colloid Interf. Sci. 80 (1981) 323-339.

[27] F. Mohammed-Azizi, S. Dib, M. Boufatit, Algerian montmorillonite clay as adsorbent for the removal of aniline from the aqueous system, Desalin. Water Treat. 30 (2011) 74-79.

[28] E. Nathaniel, A. Kurniawan, F.E. Soetaredjo, S. Ismadji, Organo-bentonite for adsorption of lead(II) ions from aqueous solution: Temperature dependent parameters of several adsorption equations, Desalin. Water Treat. 36 (2011) 280-288.
[29] K.G. Bhattacharyya, S.S. Gupta, Kaolinite, montmorillonite, and their modified derivatives as adsorbents for removal of $\mathrm{Cu}$ (II) from aqueous solution, Sep. Purif. Technol. 50 (2006) 388-397.

[30] M.J. Sanchez-Martin, M.S. Rodriguez-Cruz, M.S. Andrades, M. Sanchez-Camazano, Efficiency of different clay minerals modified with a cationic surfactant in the adsorption of pesticides: Influence of clay type and pesticide hydrophobicity, Appl. Clay Sci. 31 (2006) 216-228.

[31] B.N. Chen, C.W. Hui, G. McKay, Film-pore diffusion modeling and contact time optimization for the adsorption of dyestuffs on pith, Chem. Eng. J. 84 (2001) 77-94.

[32] J.F. Gao, J.H. Wang, Q. Yuan, C. Yang, S.Y. Wang, Y.Z. Peng, Utilization of agricultural waste chestnut shell for the removal of reactive brilliant Red K-2G from aqueous solution, Desalin. Water Treat. 36 (2011) 141-151.

[33] M. Achak, A. Hafidi, N. Ouazzani, S. Sayadi, L. Mandi, Low cost biosorbent "banana peel" for the removal of phenolic compounds from olive mill wastewater: Kinetic and equilibrium studies, J. Hazard. Mater. 166 (2009) 117-125.

[34] G. Annadurai, R.S. Juang, D.J. Lee, Use of cellulose-based wastes for adsorption of dyes from aqueous solutions, J. Hazard. Mater. 92 (2002) 263-274.

[35] L. Wang, A. Wang, Adsorption characteristics of Congo Red onto the chitosan/montmorillonite nanocomposite, J. Hazard. Mater. 147 (2007) 979-985.

[36] F.C. Wu, R.L. Tseng, R.S. Juang, Comparative adsorption of metal and dye on flake- and bead-types of chitosans prepared from fishery wastes, J. Hazard. Mater. 73 (2000) 63-75.

[37] C.H. Zhou, Emerging trends and challenges in synthetic claybased materials and layered double hydroxides, Appl. Clay Sci. 48 (2010) 1-4.

[38] D. Zhang, C.H. Zhou, C.X. Lin, D.S. Tong, W.H. Yu, Synthesis of clay minerals, Appl. Clay Sci. 50 (2010) 1-11.

[39] P. Turan, M. Dogan, M. Alkan, Uptake of trivalent chromium ions from aqueous solutions using kaolinite, J. Hazard. Mater. 148 (2007) 56-63.

[40] Y.F. Chen, M.C. Wang, M.H. Hon, Phase transformation and growth of mullite in kaolin ceramics, J. Eur. Ceram. Soc. 24 (2004) 2389-2397.

[41] M.H. Karaoğlu, M. Doğan, M. Alkan, Removal of cationic dyes by kaolinite, Microporous Mesopororous Mater. 122 (2009) 20-27.

[42] M. Alkan, O. Demirbas, M. Dogan, Electrokinetic properties of kaolinite inmono and multivalent electrolyte solutions, Microporous Mesopororous Mater. 83 (2005) 51-59.

[43] T.C.G. Kibbey, K.F. Hayes, Partitioning and UV absorption studies of phenanthrene on cationic surfactant-coated silica, Environ. Sci. Technol. 27 (1993) 2168-2173.

[44] S. Yuehong, L. Laisheng, Z. Qiuyun, W. Honghai, Equilibrium, kinetics and thermodynamic studies for sorption of chlorobenzenes on CTMAB modified bentonite and kaolinite, J. Hazard. Mater. 173 (2010) 47-53.

[45] D.L. Guerra, V.L. Leidens, R.R. Viana, C. Airoldi, Amazon kaolinite functionalized with diethylenetriamine moieties for $\mathrm{U}(\mathrm{VI})$ removal: Thermodynamic of cation-basic interactions, J. Hazard. Mater. 180 (2010) 683-692.

[46] Y. Asao, T. Morikawa, M. Okamoto, M. Hamao, H. Matsuda, O. Muraoka, D. Yuan, M. Yoshikawa, Structures of acetylated oleanane-type triterpene saponins, rarasaponins IV, V, and VI, and Anti-hyperlipidemic constituents from the pericarps of Sapindus rarak, Chem. Pharm. Bull. 57 (2009) 198-203.

[47] R.T. Yang, Gas Separation by Adsorption Process, Imperial College Press, London, 1997.

[48] D.D. Do, Adsorption Analysis: Equilibria and Kinetics, vol. 2, Imperial College Press, London, 1998.

[49] S. Ismadji, S.K. Bhatia, A modified pore-filling isotherm for liquid phase adsorption in activated carbon, Langmuir 17 (2001) 1488-1498.

[50] R. Sips, Combined form of Langmuir and Freundlich equations, J. Chem. Phys. 16 (1948) 490-495. 
[51] W. Plazinski, W. Rudzinski, A. Plazinska, Theoretical model of sorption kinetics including a surface reaction mechanism: A review, Adv. Coll. Interf. Sci. 152 (2009) 2-13.

[52] S. Lagergren, Zur theorie der sogenannten adsorption gelöster stoffe, Kungliga Svenska Vetenskapsakademiens Handlingar 24 (1898) 1-39.
[53] G. Blanchard, M. Maunaye, G. Martin, Removal of heavy metals from waters by means of natural zeolites, Water Res. 18 (1984) 1501-1507. 